\section{Polacy i Zagłada Nowa szkoła historyczna}

Alina Molisak

TEKSTY DRUGIE 2020, NR 3, S. 130-135

DOI: $10.18318 /$ td.2020.3.8 | ORCID: 0000-0002-1862-8782

$\mathbf{K}^{\mathrm{s}}$ siążka Les Polonais et la Shoah. Une nouvelle école historique [Polacy i Zagłada. Nowa szkoła historyczna] to pokłosie konferencji zorganizowanej w Paryżu (21-22 lutego 2019 roku) ${ }^{1}$. Ta obszerna publikacja zawiera dwadzieścia artykułów - część z nich została poświęcona zjawiskom bardziej ogólnym: powstaniu „nowej szkoły historycznej" w Polsce, przeobrażeniom dyskursu historycznego w ostatnich dziesięcioleciach, nowym ujęciom i redefinicji znanych kategorii (Jan Tomasz Gross, Jean-Charles Szurek, Jacek Leociak, Elżbieta Janicka, Andrzej Leder, Audrey Kichelewski); inne zaś tworzą zespół interdyscyplinarnych, różnotematycznych studiów (Barbara Engelking, Jan Grabowski, Alina Skibińska, Agnieszka Haska, Karolina Panz, Joanna Tokarska-Bakir, Jean-Yves Potel, Anna Bikont, Fleur Kuhn-Kennedy, Barbara Lambauer, Tal Bruttmann) oraz dotyczą diagnoz interferencji

1 Les Polonais et la Shoah. Une nouvelle école historique, ed. A. Kichelewski, J. Lyon-Caen, J.-Ch. Szurek, A. Wieviorka, CNRS Éditions, Paris 2019.
Alina Molisak - dr hab., pracuje w Instytucie Literatury Polskiej na Wydziale Polonistyki Uniwersytetu Warszawskiego. Nauczała również na Uniwersytecie Humboldtów (Berlin 2007/2008) oraz na Uniwersytecie w Hamburgu (2015/2016). Należy do Gesellschaft für europäisch-jüdische Literaturstudien, Polskiego Towarzystwa Studiów Jidyszystycznych i Polskiego Towarzystwa Studiów Żydowskich. Opublikowała: Judaizm jako los. Rzecz o Bogdanie Wojdowskim (2004) oraz Żydowska Warszawa-żydowski Berlin (2016). Współredaktorka m.in. książek: Polish and Hebrew Literature and National Identity (2010); Nach dem Vergessen. Rekurse aufdem Holocaust in Ostmitteleuropa nach 1989 (2010); Ślady obecności (2010); Żydowski Polak - polski Żyd. Problem tożsamości w literaturze polsko-żydowskiej (2011); Galician Polyphony. Places and Voices (2015); Pomniki pamięci. Miejsca niepamięci. (2017), The Trilingual Literature of Polish lews from Different Perspectives. In Memory of I.L. Peretz (2017); Tożsamość po pogromie. Świadectwa i interpretacje Marca '68 (2019). 
historii i polityki (Valentin Behr, Ewa Tartakowsky) czy perspektywy komparatystycznej w badaniach nad ludobójstwem (Sidi N'Diaye). Redaktorzy całość podzielili na trzy części: tę poświęconą nowej polskiej szkole badań nad Zagładą (Prolog. Wstronęnowej polskiej szkoty historii Holokaustu), gdzie znalazły się teksty Jana Tomasza Grossa, Jean-Charles'a Szurka i Jacka Leociaka, partię zatytułowaną W sercu Holokaustu, Żydzi w okupowanej Polsce oraz część określoną jako Potem. Historia, wspomnienia, kontrpamięci. Nie sposób w tak krótkiej recenzji omówić wszystkie, niezwykle interesujące artykuły, zatem jedynie na wybrane spośród nich chciałabym zwrócić uwagę².

Publikację otwiera tekst Jana Tomasza Grossa ${ }^{3}$, który, wychodząc od opisu rozwoju własnych zainteresowań badawczych, zwraca uwagę na to, jak istotnym elementem w studiach nad okupacją niemiecką są relacje polsko-żydowskie i jak niewiele uwagi poświęcano im w latach powojennych. Krytyczna lektura opublikowanych relacji ocalałych (Ten jest z ojczyzny mojej...) prowadzi wszak do fundamentalnego pytania o to, jak wyglądała rzeczywistość Zagłady postrzegana z innej perspektywy - tych, którzy nie ocaleli, albo z punktu widzenia tych, którzy spisali swe traumatyczne doświadczenia, ale nie dotarły one przez wiele lat do większej liczby odbiorców, pozostały jedynie w archiwach. Gross celnie zwraca uwagę na to, że używany często, by objaśnić brak pomocy dla Żydów, argument lęku („baliśmy się pomagać ze względu na represje") jest niezwykle słaby. Represje niemieckie dotyczyły wszak wielu sfer zaangażowania: tajnego nauczania czy różnych innych form udziału w ruchu oporu, w których, mimo zagrożenia, aktywnie uczestniczyła polska społeczność. Dodatkowo osłabiają przydatność takiego rozumowania powojenne reakcje polskie, w tym fala przemocy antysemickiej czy obawy Sprawiedliwych o to, by ujawniać ich szlachetne czyny. Wiele uwagi poświęcił autor w tej

2 Zbiór artykułów poprzedza wstęp, w którym Jean-Charles Szurek i Annette Wieviorka nie tylko wskazują najważniejsze omawiane i analizowane w publikacji problemy czy zwracają uwagę na konkretne teksty. Mowa tam również o wyjątkowej sytuacji: o zakłócaniu konferencji naukowej przez zorganizowaną grupę polskich antysemitów. Zszokowani zachowaniami tych osób byli nie tylko naukowcy czy słuchacze obecni na konferencji. Zjawisko analizowała Judith Lyon-Caen, jedna z organizatorek wydarzenia. Zob. Les historiens face au révisionnisme polonais, "La Vie des idées", 5 avril 2019. Patrz: https://laviedesidees.fr/Les-historiens-face-au-revisionnisme-polonais.html.

3 Opublikowane wystąpienie Jana Tomasza Grossa poprzedza mowa wygłoszona na jego powitanie w Collège de France (21 lutego 2019 roku) przez Patricka Boucheron'a, który podkreślił zasługi autora Sąsiadów dla rozwoju polskiej nowej szkoły historii w badaniach nad Zagładą i przypomniał, że Jan Tomasz Gross jest czwartym Polakiem (po Adamie Mickiewiczu, Jerzym Grotowskim i Bronisławie Geremku) przemawiającym w tak wyjątkowym miejscu. 
wypowiedzi roli, jaką odegrały w XX wieku pokolenia inteligencji - w zapisywaniu historii i kształtowaniu obrazu dziejów, wykorzystywaniu rozmaitej symboliki do kreowania narracji o przeszłości. Doceniając wielką pracę,jakiej podjęli się naukowcy związani z Centrum Badań nad Zagładą, Gross podkreśla zasadniczą zmianę w polskich badaniach nad dziejami okupacji. Powraca przy tym do ważnej uwagi dotyczącej postrzegania historii Zagłady jako integralnej części polskiej przeszłości, uznając, że to, co bywało wyparte, przemilczane czy manipulowane, odzyskuje właściwe miejsce w dziejach.

Ważnym głosem jest wypowiedź Jean-Charles'a Szurka, który omawia zmiany, jakie można dostrzec w polskiej historiografii. Szkicując przeobrażenia, omawia syntetycznie kolejne fazy pisania o wojennej przeszłości, m.in. założenia tużpowojenne (np. propagandowy antyfaszyzm) towarzyszące konstruowaniu obrazu eksterminacji europejskich Żydów. Tekst Szurka, noszący tytuł Etapy świadomości, to także zwrócenie uwagi na zasadniczą zmianę myślenia o czasach okupacji - przywrócenie żydowskiej tożsamości ofiarom, które często określano jedynie jako obywateli konkretnego państwa („polonizacja ofiar albo ich anonimizacja" ${ }^{\prime \prime}$. Istotnym elementem obecnych zmian, wywołanych przede wszystkim głośnymi i szeroko dyskutowanymi publikacjami (Jana Błońskiego, Grossa i innych) jest coraz bardziej powszechna świadomość fundamentalnej różnicy losu mieszkańców okupowanej Europy - unaocznienie, że dla Żydów wyrokiem śmierci był sam fakt istnienia, oraz zwrócenie uwagi w badaniach na całość społeczeństwa, a nie tylko na konkretnie wyróżnionych Sprawiedliwych czy - ukazywanych jako margines - szmalcowników ${ }^{5}$. W takiej perspektywie można postrzegać zmianę paradygmatu zrywającego z istniejącymi narracjami (posługującymi się binarnym opisem: opór versus współpraca, prześladowania versus solidarność) i pracę tych uczonych, którzy traktują analizę przeszłości wieloaspektowo.

4 Szurek przytacza znamienny fakt: podczas odsłonięcia międzynarodowego pomnika ofiar faszyzmu w muzeum Auschwitz 16 kwietnia 1967 roku ówczesny premier, Józef Cyrankiewicz (były więzień Auschwitz), wymieniając wszystkie kategorie ofiar obozu, pominął Żydów. Doprowadziło to do rezygnacji Roberta Waitza, przewodniczącego Międzynarodowego Komitetu Oświęcimskiego (również byłego więźnia); można o tym zdarzeniu przeczytać m.in. tu: https:// www.jta.org/1967/04/18/archive/jews-from-many-lands-revisit-auschwitz-in-second-dayof-prayers.

5 Szurek wskazuje też, że seria kluczowych pytań dotyczących relacji polsko-żydowskich w latach okupacji została postawiona przez Jana Tomasza Grossa jeszcze przed publikacją Sąsiadów w książce Upiorna dekada, zob. J.T. Gross Upiorna dekada. Trzy eseje o stereotypach na temat Żydów, Polaków, Niemców i komunistów, 1939-1948, Universitas, Kraków 1996. 
Artykuł Jacka Leociaka, jednego z przedstawicieli Ośrodka Badań nad Zagładą, to podsumowanie i prezentacja dotychczasowego dorobku całego zespołu. Autor, przypominając o różnorodnej tematyce oraz o rozmaitych metodologiach stosowanych przez naukowców zajmujących się w Polsce Szoa, wskazał na ważną cechę wspólną środowiska - nieapologetyczne podejście do historii. Podkreślił, że Zagłada stanowi także w polskich dziejach jedno z kluczowych doświadczeń XX wieku. Prace założonego w 2013 roku Centrum Badań nad Zagładą Żydów (będącego częścią Instytutu Filozofii i Socjologii PAN) koncentrują się na tym fundamentalnym wydarzeniu. Wyniki prac publikowane są w wydawanym przez Centrum roczniku oraz w książkach indywidualnych i zbiorowych autorstwa członków tej grupy naukowców ${ }^{6}$. Wśród publikacji warto też wskazać na dwie ważne serie: opracowań poświęconych najtrudniejszym tematom ${ }^{7}$ oraz wydanych dotychczas tomów „Biblioteki świadectw Zagłady”. Badacze związani z Centrum brali i biorą udział we współpracy międzynarodowej z ośrodkami zajmującymi się historią Szoa. Autor prezentacji wskazuje również na innych polskich naukowców, współtworzących nową szkołę historyczną, wymienia kilkoro spośród nich (Joanna Tokarska-Bakir, Piotr Forecki, Elżbieta Janicka, Anna Bikont, Mirosław Tryczyk). Leociak nie wspomniał jednak o tym (a szkoda!), że od wielu lat publikują także prace dotyczące badań nad Zagładą historycy literatury (Sławomir Buryła, Dorota Krawczyńska, Aleksandra Ubertowska, Bożena Umińska, Tomasz Żukowski, Katarzyna Chmielewska, Justyna Kowalska-Leder, Marta Tomczok ${ }^{8}$, Paweł Wolski, Bartłomiej Krupa i inni); ich dorobek przynależy z pewnością do nowej polskiej szkoły badań nad Zagładą. Wymienionych autorów łączy wspólnota wartości wyrażająca się w głębokim przekonaniu o tym, iż doświadczenie Zagłady stanowi istotne wyzwanie naukowe i moralne oraz że nie wolno podporządkować analiz i interpretacji

6 Wykaz publikacji znaleźć można na stronie Centrum, patrz: https://www.holocaustresearch. $\mathrm{pl} /$ index.php?show $=162$.

7 W tej pierwszej serii ukazały się dotychczas: B. Engelking "Szanowny panie gistapo...". Donosy do władz niemieckich w Warszawie i okolicach w latach 1940-1941; ). Grabowski „ja tego Żyda znam...." Szantażowanie Żydów w Warszawie, 1939-1943; B. Engelking, J. Grabowski „Żydów łamiących prawo należy karać śmierciq̨" . "Przestępczość" Żydów w Warszawie, 1939-1942; A. Haska "Jestem Żydem, chcę wejść". Hotel Polski w Warszawie, 1943; A. Skibińska, T. Markiel "/akie to ma znaczenie, czy zrobili to z chciwości?". Zagłada domu Trynczerów.

8 Na Uniwersytecie Śląskim działa Centrum Studiów nad Dyskursami Zagłady; pod redakcją Marty Tomczok ukazuje się pismo "Narracje o Zagładzie" - patrz: http://www.noz.us.edu.pl/ en/start-2/. 
jakiejkolwiek ideologii czy tzw. polityce historycznej. Zmianę paradygmatu wiąże też Leociak z trzema jeszcze aspektami: znacząco większym dostępem do źródeł (w tym m.in. do dokumentu osobistego), wyznaczaniem, w polskiej przestrzeni, nowych pól badawczych dotyczących całej społeczności, relacji polsko-żydowskich, pozycji Kościoła, roli administracji etc. Trzeci aspekt to debata nad kategorią wprowadzoną do dyskursu historycznego przez Raula Hilberga (kaci-ofiary-świadkowie), zwłaszcza nowe podejście zarówno do figury świadka, jak i do ofiar.

Nawiązaniem do namysłu nad kategorią świadka są dwa inne artykuły Agnieszki Haskiej oraz Elżbiety Janickiej. Studium Haskiej dotyczy interesującego przypadku funkcjonowania cudzoziemców w okupowanej Warszawie. Janicka z kolei koncentruje się na redefinicji używanych dotychczas kategorii, proponując inne rozumienie postaci „świadka”. Trafnie wskazuje na konkret historyczny, jakim były relacje polsko-żydowskie, zarówno przed wybuchem wojny, jak i w trakcie okupacji. Podkreśla kluczowe dla tych stosunków: dominację grupy większościowej, wykluczenie ze wspólnoty obywatelskiej, funkcjonowanie w kulturowej ramie, która w zasadniczy sposób wyznaczyła pole wydarzeń. Nie tyle na obrzeżach, co w centrum rozegrała się Zagłada, niemiecka nazistowska zbrodnia na Żydach, gdzie polscy świadkowie byli obserwatorami uczestniczącymi i gdzie funkcjonował wzór kultury polskiej, którego strukturalną częścią był antysemityzm. Wydaje się, że artykuły innych autorów wzmacniają wymowę rozważań Janickiej, gdy rozpatrywane są kolejne aspekty przeszłości w tekstach Grabowskiego, Skibińskiej, Engelking, Panz, Bruttmanna. Z kolei Lambauer sięga do wcześniejszych zjawisk przemocy antyżydowskiej, podobnie jak Tokarska-Bakir pisząca o latach powojennych. Obie dostrzegają ów wzór kultury na tę przemoc pozwalający; w latach powojennych dołożony do tegoż modelu zostanie jeszcze jeden element (pisze o tym Kichelewski) mitycznej „żydowskiej niewdzięczności”. Dopełnieniem tej refleksji są analizy wybranych spośród powstałych narracji (Potel pisze o Klukowskim, Szlenglu, Papuszy i Langfus, zaś Kuhn-Kennedy o Lili Berger). Dlaczego tak zasadniczym głosem wybrzmiewa tekst Janickiej? Otóż także dlatego, że są dlań istotnym kontekstem inne jeszcze artykuły dotyczący nauczania o Zagładzie (Tartakowsky zajmuje się czasem od reformy edukacji w 2017 roku) oraz analizujący formułę działalności IPN (Behr) jako oficjalnego centrum produkcji historii, czy wreszcie dekonstruujące biografię Sendlerowej rozważania Bikont. Innym zaś, równie interesującym głosem, współbrzmiącym także z tym, co napisała Janicka, również przywołująca ludobójstwo w Rwandzie, jest tekst napisany przez N’Diaye, poświęcony 
refleksjom na temat wyobraźni nienawiści oraz performatywnej sile zinternalizowanych mitów i fantazji.

Zbulwersowana zachowaniem zorganizowanej grupy polskiej publiczności francuska minister nauki i szkolnictwa wyższego Frédérique Vidal wysłała list protestacyjny swojemu polskiemu odpowiednikowi, Jarosławowi Gowinowi ${ }^{9}$. Bezprecedensowe antysemickie wystąpienia towarzyszyły wydarzeniu akademickiemu, jakim była konferencja. Wspominają o tym autorzy wielu tekstów, bardziej szczegółowo relacjonują całą sprawę także redaktorzy, którzy napisali wstęp do książki. W trakcie spotkania nad konsekwencjami Szoa dla świadomości (i nieświadomości) polskiego społeczeństwa zastanawiał się Andrzej Leder, stawiając tezę, iż wiedza o dramatycznym doświadczeniu Zagłady funkcjonuje bardziej w stłumieniu czy przemilczeniu niż opowieści. Według niego przebywanie w „strefie doświadczeń Zagłady” ma poważne międzypokoleniowe konsekwencje, zaś używając narzędzi psychoanalizy, możemy zobaczyć narastanie lęku przed prawdą o nas samych. Wynika stąd również obawa przed wolnością myślenia. W takiej perspektywie dostrzec można najbardziej niszczycielski dla społeczności aspekt dziedzictwa Zagłady.

\section{Abstract}

\section{Alina Molisak}

UNIVERSITY OF WARSAW

The Poles and the Holocaust: A New History School

Molisiak reviews an important publication that appeared in France in 2019. This book presents a new Polish historical school. He collects the latest works of researchers on the Holocaust and Polish-Jewish relations during the Second World War.

\section{Keywords}

Shoah, Polish historiography, contemporary discussions

9 Piszą o tym autorzy wstępu. 